\title{
Voltammetric Determination of Ascorbic Acid in Pharmaceutical Formulations Using Modified lodine-Coated Platinum Electrode
}

\author{
Determinación voltamétrica del ácido ascórbico en \\ formulaciones farmacéuticas utilizando un electrodo de \\ platino modificado recubierto de yodo
}

Mohammad Amayreh $^{1 * \mathbb{D}}$, Wafa Hourani ${ }^{2}$, Mohammad Khair Hourani ${ }^{3}$ (D)

JOURNAL VITAE

School of Pharmaceutical and Food Sciences ISSN 0121-4004 | ISSNe 2145-2660 University of Antioquia Medellin, Colombia

Filliations

1 Department of Chemistry, Faculty of Science, Al-Balqa Applied University, P.O. Box 19117, Al-Salt, Jordan

${ }^{2}$ Faculty of Pharmacy, Philadelphia University, Amman, Jordan

${ }^{3}$ Department of Chemistry, the University of Jordan, Amman, Jordan
Mohammad Amayreh

mohammad.amayreh@bau.edu.jo

Received: 07 May 2021

Accepted: 06 June 2021

Published: 01 July 2021

\begin{abstract}
Background: Despite the high reactivity of the platinum electrode, the iodine-coated platinum electrode shows obvious inertness toward adsorption and surface processes. For that, iodine-coated platinum electrodes accommodate themselves to interesting voltammetric applications. Objectives: This study reports using the modified iodine-coated polycrystalline platinum electrode as a voltammetric sensor for ascorbic acid determination in pharmaceutical formulations. Methods: The developed voltammetric method based on recording cyclic voltammograms of ascorbic acid at iodine-coated electrode The optimized experimental parameters for the determination of ascorbic acid were using $0.1 \mathrm{M} \mathrm{KCl}$ as a supporting electrolyte with a scan rate of $50 \mathrm{mV} / \mathrm{s}$. Results: The anodic peak related to ascorbic acid oxidation was centered at nearly $0.28 \mathrm{~V}$. An excellent and extended linear dependence of the oxidative peak current on the concentration of ascorbic acid was observed in the range $2.84 \times 10^{-3}-5.68 \mathrm{mM}$. The limit of detection (LOD) and limit of quantitation (LOQ) were $1.0 \mu \mathrm{M}$ and $3.01 \mu \mathrm{M}$, respectively, attesting to the method's sensitivity. The investigation for the effect of potential interference from multivitamin tablet ingredients (vitamins B1, B6, B12, folic acid, citric acid, sucrose, glucose, and zinc) indicated specific selectivity toward ascorbic acid and the absence of any electrochemical response toward these components. Recovery results in the range $98.93 \pm 2.78-99.98 \pm 5.20$ for spiked standard ascorbic acid in pharmaceutical formulations further confirmed the potential applicability of the developed method for the determination of ascorbic acid in real samples. Conclusions: The developed method was successfully applied to the analysis of ascorbic acid (vitamin C), and the obtained results were in good agreement with the labeled values; besides, the statistical tests indicated no significant difference at $p=0.05$ with a $95 \%$ confidence level.
\end{abstract}

Keywords: ascorbic acid analysis, pharmaceutical formulation, voltammetric analysis, iodinecoated platinum electrode, modified platinum electrode. 


\section{RESUMEN}

Antecedentes: A pesar de su alta reactividad, el electrodo de platino recubierto de yodo muestra una inercia evidente hacia la adsorción y los procesos superficiales. Por ello, los electrodos de platino recubiertos de yodo se adaptan a interesantes aplicaciones voltamétricas. Objetivos: Este estudio informa sobre el uso del electrodo de platino policristalino recubierto de yodo modificado como sensor voltamétrico para la determinación del ácido ascórbico en formulaciones farmacéuticas. Métodos: El método voltamétrico desarrollado se basa en el registro de voltamperogramas cíclicos del ácido ascórbico en el electrodo recubierto de yodo Los parámetros experimentales optimizados para la determinación del ácido ascórbico fueron utilizando $\mathrm{KCl}$ 0,1 M como electrolito de soporte con una velocidad de barrido de $50 \mathrm{mV} / \mathrm{s}$. Resultados: El pico anódico relacionado con la oxidación del ácido ascórbico se centró en casi $0,28 \mathrm{~V}$. Se observó una excelente y extendida dependencia lineal de la corriente

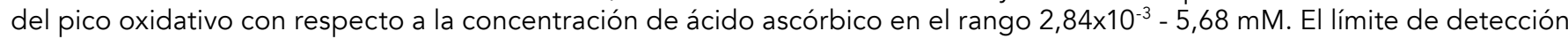
(LOD) y el límite de cuantificación (LOQ) fueron 1,0 $\mu \mathrm{M}$ y 3,01 $\mu \mathrm{M}$, respectivamente, lo que demuestra la sensibilidad del método. La investigación del efecto de la interferencia potencial de los ingredientes de las tabletas multivitamínicas (vitaminas B1, B6, B12, ácido fólico, ácido cítrico, sacarosa, glucosa y zinc) indicó una selectividad específica hacia el ácido ascórbico y la ausencia de cualquier respuesta electroquímica hacia estos componentes. Los resultados de recuperación en el rango de

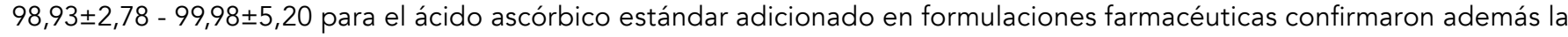
potencial aplicabilidad del método desarrollado para la determinación del ácido ascórbico en muestras reales. Conclusiones: El método desarrollado se aplicó con éxito al análisis de ácido ascórbico (vitamina C), y los resultados obtenidos coincidieron con los valores etiquetados; además, las pruebas estadísticas no indicaron diferencias significativas a $p=0,05$ con un nivel de confianza del 95\%.

Palabras clave: análisis de ácido ascórbico, formulación farmacéutica, análisis voltamétrico, electrodo de platino recubierto de yodo, electrodo de platino modificado.

\section{INTRODUCTION}

L-ascorbic acid $\left(\mathrm{C}_{6} \mathrm{H}_{8} \mathrm{O}_{6}\right)$ is the trivial name of Vitamin $\mathrm{C}$, scheme 1, considered one of the essential watersoluble vitamins for human health. It is found in various biological systems and fresh foodstuff (1). The human body required ascorbic acid for normal physiological functions such as the synthesis and metabolism of tyrosine, folic acid, and tryptophan (2). At the same time, ascorbic acid deficiency is associated with many diseases such as anemia infections and scurvy (3).

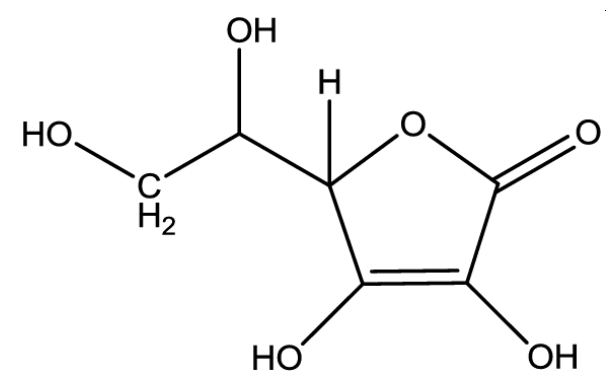

Scheme 1. The chemical structure of ascorbic acid

Additionally, synthetic ascorbic acid is available in several types of supplements such as tablets, capsules, chewable tablets, crystalline powder, effervescent tablets, and liquid forms (4). Several methods have been reported in the literature for the quantitative determination of ascorbic acid in various matrices. These methods include chromatography $(5,6)$, titration (7), spectroscopy (8-12), fluorimetry (13), and flow injection analysis (14). However, some of the reported methods are time-consuming, and some are expensive and need skilled personnel.
Alternatively, electrochemical methods are considered a promised methods because of the short time response, low cost, sensitivity, and simplicity of instrumentation (15).

The modification of electrode surface is a quest to render electrochemical function that is not possible or difficult to achieve by using conventional electrodes. The goals of the improvement process include increasing selectivity, sensitivity, chemical and electrochemical stability, large usable potential window, and improving resistance to fouling (contaminating) (16).

Therefore, the avenues have opened toward the modification of solid electrodes (17). For instance, iodine adsorbed on the surface of platinum electrode simplifies background behavior and enhances voltammetry's reproducibility (18). Also, coating surface of solid electrodes alters the mechanisms and kinetics of reactions run at the surface of electrode. lodine is one of the anions adsorbed to an electrode surface. There are two ways to achieve chemisorption process; from vacuum or solution to create a stable chemisorbed monolayer; subsequently, the iodine-coated platinum electrode is evacuated or rinsed (19). The iodine is adsorbed to platinum electrode surface at potential $0.2 \mathrm{~V}$ vs. $\mathrm{Ag} / \mathrm{AgCl}$ or SCE reference electrodes (20), which is known as the double layer potential. At the polycrystalline platinum electrode surface, the iodine anions reaction from the solution leads to spontaneous chemisorption of iodide anion to form stable neutral iodine atoms accompanied by an evolution of hydrogen gas. The adsorbed 
iodine at platinum electrode surface is less reactive toward electrochemical oxidation compared with the free iodine anion in solution (21) and depends on the potential of electrode (22). If the potential is scanned lower than $-0.2 \mathrm{~V}$, the chemisorbed iodine could be desorbed from the electrode surface, reducing of hydrogen ions and generates of hydrogen gas (21). Also, the iodine desorption rate from platinum electrode surface increases as the potential becomes more negative (22). In the positive direction of scanning, the chemisorbed iodine begins to desorb from the electrode surface at a potential of $1.0 \mathrm{~V}(20)$. Studies have reported that carbon monoxide (CO) completely desorbed iodine from the surface of platinum electrode at potentials less than $0.35 \mathrm{~V}$, while at higher potentials, the desorption is incomplete (23).

lodine-coated platinum electrode has been used for the electrochemical determination of organic and non-organic species in many studies (24-32). lodine-coated platinum electrode is remarkable for the simplicity in preparation, application, and use of environmentally friendly chemical reagents. The simplicity of the method's instrumentation motivates our interest in this research. This work develops a simple method for ascorbic acid determination in pharmaceutical formulations.

\section{EXPERIMENTAL}

\section{Materials and apparatus}

A potentiostat (PAR Model 362, EG \& G) connected to a computer via a GPIB interface (IEEE) data acquisition was used. The data was acquired via locally modified Labview ${ }^{\circledR}$ (IEEE) software. An electrochemical cell of one compartment with one inlet/outlet for gas purging and blanketing with highly pure nitrogen was used. A $0.5 \mathrm{~mm}$ polycrystalline platinum wire purchased from Aldrich (99.99\% minimum purity certified reagent) was used as a working electrode. The immersed part of the platinum electrode was curved at the end to a U-shape to mark for a constant surface area of the immersed part of the electrode. The reference electrode was silver/silver chloride was used as a quasi-reference electrode (QRE). A 0.5 $\mathrm{mm}$ polycrystalline platinum wire (Aldrich, certified 99.99\% minimum purity) was used as an auxiliary electrode. All reagents used were analytical grade and used as received from the suppliers without further purification. Sulfuric acid (95-97\%) was supplied from Merck, L-ascorbic acid (99\%) was purchased from AnalaR, potassium iodide was purchased from Sigma-Aldrich. Ultra-pure water, Millipore-MilliO system was used for the preparation of all solutions. The nitrogen gas of five grade, 99.999\% minimum purity, was supplied from the International Jordanian Gases Company (Amman, Jordan).

The limit of detection based on the formula $\mathrm{LOD}=3.3$ ? $/ \mathrm{S}$, and the limit of quantitation based on the formula $\mathrm{LOQ}=10$ ? $/ \mathrm{S}$, where ? represents the blank signal (background current), and $S$ means the sensitivity of the calibration curve was calculated. The estimated limits were $1.0 \mu \mathrm{M}$ and $3.01 \mu \mathrm{M}$, respectively. Thus, acceptable sensitivity of the applied cyclic voltammetric method with high precision was obtained. Higher sensitivity can be obtained by using a more sensitive technique like differential pulse voltammetry (DPV). However, differential pulse voltammetry technique was not attempted on account of cyclic voltammetry provides satisfactory sensitivity for ascorbic acid determination in pharmaceutical formulations.

\section{Preparation of iodine-coated platinum electrode}

The polycrystalline platinum electrode was cleaned with a freshly prepared chromic acid $\left(\mathrm{H}_{2} \mathrm{CrO}_{4}\right)$, followed by rinsing with Millipore- $\mathrm{Q}$ water and sonicated for 10 minutes. After that, the platinum electrode was placed in contact with a supporting electrolyte solution of $0.5 \mathrm{M} \mathrm{H}_{2} \mathrm{SO}_{4}$ and conditioned between $-0.25 \mathrm{~V}$ and $1.3 \mathrm{~V}$ until obtaining a reproducible cyclic voltammogram of a polycrystalline platinum electrode, which manifests the cleanliness of the electrode surface and electrochemical cell contents (Fig.1).

After cleaning the platinum electrode, the electrode was immersed in a supporting electrolyte containing $0.5 \mathrm{M} \mathrm{H}_{2} \mathrm{SO}_{4}+0.01 \mathrm{M} \mathrm{KI}$ for five minutes under open-circuit conditions to complete the coating of the platinum electrode surface with iodine. Then the electrode was rinsed with water and $0.5 \mathrm{M} \mathrm{H}_{2} \mathrm{SO}_{4}$ solution extensively. After the coating step, the electrode was cycled in a supporting electrolyte solution between $-0.2 \mathrm{~V}$ and $+0.8 \mathrm{~V}$ at a scan rate of $50 \mathrm{mV} / \mathrm{s}$ (Fig.1). The absence of oxygen and hydrogen adsorption/desorption features provides clear evidence for the complete coverage of the platinum electrode surface with a monolayer of iodine. 


\section{Sample preparation}

The pharmaceutical formulation samples were purchased from local Jordanian pharmacies in the form of tablets and capsules. Three brands of pharmaceutical preparations were analyzed for their ascorbic acid content. The capsules of each sample were dissolved in $20 \mathrm{~mL}$ of $0.1 \mathrm{M} \mathrm{KCl}$ and sonicated for $10 \mathrm{~min}$ and left to equilibrate for $30 \mathrm{~min}$. The solution was transferred to a $100 \mathrm{~mL}$ volumetric flask and filled to the mark with $0.1 \mathrm{M} \mathrm{KCl}$. The solution was diluted to a concentration that matches the established calibration curve. A tablet of each sample was treated separately. The tablet of each brand was powdered using porcelain mortar and dissolved in $100.00 \mathrm{~mL}$ of the supporting electrolyte, $0.1 \mathrm{M} \mathrm{KCl}$; the solution of the prepared samples was sonicated for $5 \mathrm{~min}$ and left to equilibrate for $5 \mathrm{~min}$. A $5 \mathrm{~mL}$ aliquot of this solution was diluted to $50.00 \mathrm{~mL}$ with $0.1 \mathrm{M} \mathrm{KCl}$ to match the constructed calibration curve at different concentration ranges. A $10.00 \mathrm{~mL}$ of the diluted solution was placed in the electrochemical cell. The solution was bubbled with nitrogen gas (5G purity) and kept under a nitrogen gas atmosphere during the electrochemical experiment. The voltammetric analysis was conducted for ascorbic acid at the modified iodine-coated platinum electrode within a potential window started at $-0.2 \mathrm{~V}$ and finished at $0.6 \mathrm{~V}$, where the adsorbed iodine is stable.

\section{Results and discussions}

Initially, a reproducible cyclic voltammogram for the polycrystalline platinum electrode, which indicates the cleanness of the electrochemical system, was obtained (Fig1-A). The process led to a successful coating process; the cyclic voltammogram of the iodine-coated platinum electrode between potential limits of $-0.2 \mathrm{~V}$ and $0.6 \mathrm{~V}$ was displayed (Fig $1-B)$, where the adsorbed iodine was stable within this potential range. The complete absence of $\mathrm{H}_{2}$ and $\mathrm{O}_{2}$ oxidation-reduction features was the main indicator of a successful coated step.

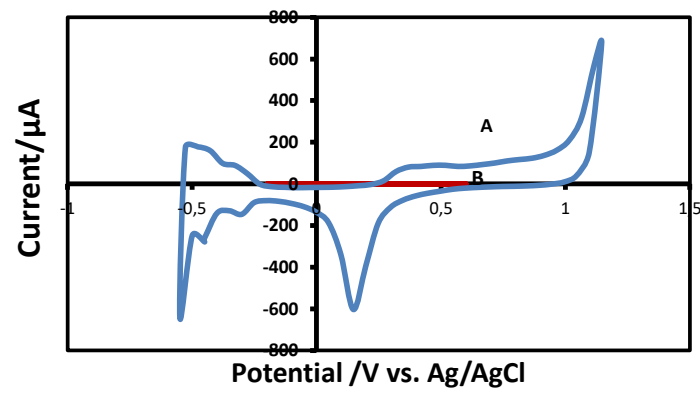

Fig.1. Cyclic voltammogram curves of $(A)$ polycrystalline platinum electrode and $(\mathrm{B})$ the same electrode after adsorption of iodine from $0.01 \mathrm{M} \mathrm{KI}$ in $0.5 \mathrm{M} \mathrm{H}_{2} \mathrm{SO}_{4}$ solution
The effect of varying supporting electrolytes on the anodic peak current of ascorbic acid oxidation was investigated. A $0.5 \mathrm{M} \mathrm{H}_{2} \mathrm{SO}_{4}(\mathrm{pH}=0.3)$, phosphate buffer of $\mathrm{pH}=3.5$, and $0.1 \mathrm{M} \mathrm{KCl}(\mathrm{pH}=7)$ solution were used. As displayed in Figure 2, various oxidation peak current was obtained for ascorbic acid oxidation with different supporting electrolyte solutions. The highest oxidation peak current was obtained in $0.1 \mathrm{M}$ $\mathrm{KCl}$ (the highest $\mathrm{pH}$ value), 45.47 $\pm 0.09 \mathrm{mV}$. Therefore, $0.1 \mathrm{M} \mathrm{KCl}$ solution was considered a supporting electrolyte in the following study.

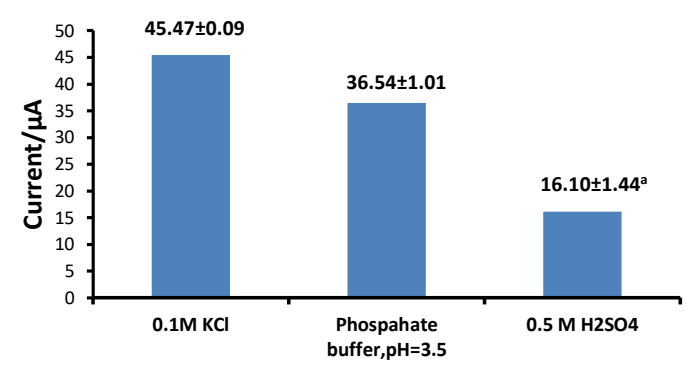

Fig.2. Effect of type of supporting electrolyte on the electrochemical signal of ascorbic acid at iodine-coated platinum electrode, Ascorbic acid; 0.57mM. Supporting electrolytes: $\mathrm{H}_{2} \mathrm{SO}_{4} 0.5 \mathrm{M}(\mathrm{pH}=0.3)$; phosphate buffer, $\mathrm{pH}=3.5$; $\mathrm{KCl} 0.1 \mathrm{M}(\mathrm{pH}=7) \mathrm{n}=3$; scan rate, $50 \mathrm{mV} / \mathrm{sec}$. Numbers above the bars $=$ mean \pm SD.

The effect of scan rate on the obtained anodic peak current of ascorbic acid was studied. As presented in Fig.3, there is a linear relationship between the square root of scan rate and oxidation peak current of ascorbic acid over the range of $10-100 \mathrm{mV} / \mathrm{s}$, which suggested a diffusion-controlled irreversible oxidation process of ascorbic acid at the iodinecoated platinum electrode.

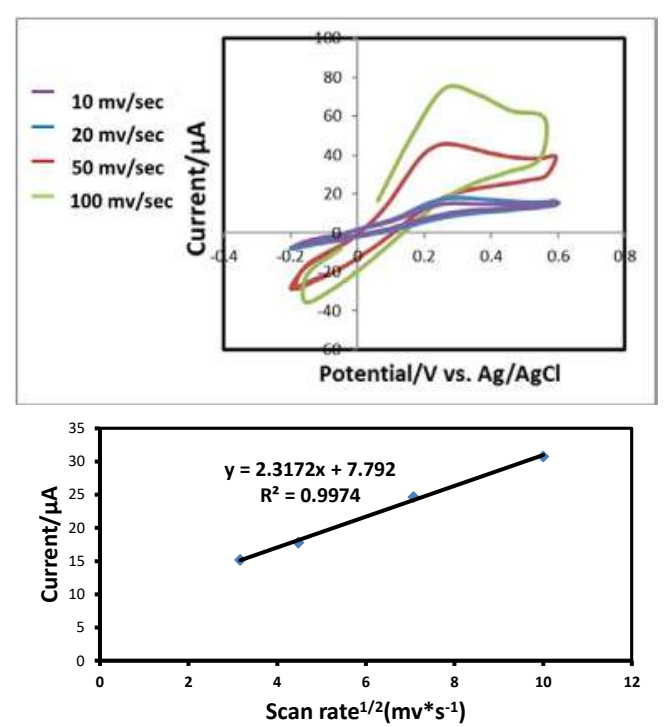

Fig 3.a) Cyclic voltammograms of iodine-coated platinum electrode in $0.1 \mathrm{M} \mathrm{KCl}$ and 50 ppm of ascorbic acid recorded at $10,20,50$, and $100 \mathrm{mv} / \mathrm{s}$. b) The least square line for the ascorbic acid oxidation peak current vs. the square root of scan rate. 
The obtained cyclic voltammograms for the iodinecoated platinum electrode in a series of ascorbic acid standard solutions show that the oxidation current increased steadily with ascorbic acid concentration (Fig.4). Three voltammograms were recorded for each standard solution. The anodic peak current was extracted for each cyclic voltammogram.

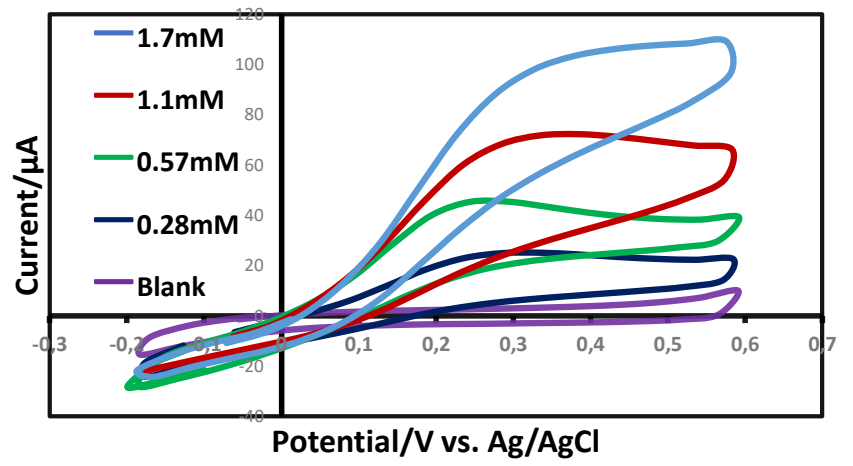

Fig 4. Cyclic voltammograms of iodine-coated platinum electrode in $0.1 \mathrm{M} \mathrm{KCl}$ solution containing $0.28,0.57,1.1$, and $1.7 \mathrm{mM}$ of ascorbic acid. All the scans were recorded at a scan rate of $50 \mathrm{mV} / \mathrm{s}$.

Plotting the anodic peak current variation against ascorbic acid concentration gave a straight and extended dynamic range with concentrations ranging between $2.84 \mu \mathrm{M}-5.68 \mathrm{mM}$ The calibration curve displayed in Fig 5 shows that all the variability of the response data around its mean; $R^{2}=0.9969$, and the calibration equation is given by

$$
\mathrm{I}_{\mu \mathrm{A}}=65.248 \mathrm{C}_{\text {Ascorbic acid }}+3.06
$$

Where I represents the anodic peak current which attributed to the ascorbic acid oxidation as it is shown in the following equation:

\section{Ascorbic acid $\rightarrow$ dehydro-ascorbic acid $+2 \mathrm{H}^{+}+2 \mathrm{e}$}

The precision, that is, the repeatability of the method, was assessed by extracting the anodic peak current of the recorded cyclic voltammograms for a solution containing $0.28 \mathrm{mM}$ ascorbic acid. The achieved coefficient of variation for 10 successive measurements was $1.36 \%$, indicating the high precision of the developed method.

The limit of detection based on the formula $L O D=3.36 / S$, and the limit of quantitation based on the formula $L O Q=106 / S$, where 6 represents the blank signal (background current), and $S$ means the sensitivity of the calibration curve was calculated. The estimated limits were $1.0 \mu \mathrm{M}$ and $3.01 \mu \mathrm{M}$, respectively. Thus, acceptable sensitivity of the applied voltammetric method with high precision was obtained. Higher sensitivity can be achieved by applying a more sensitive technique like differential pulse voltammetry (DPV). However, differential pulse voltammetry was not attempted because cyclic voltammetry provides satisfactory sensitivity for ascorbic acid determination in pharmaceutical formulations.

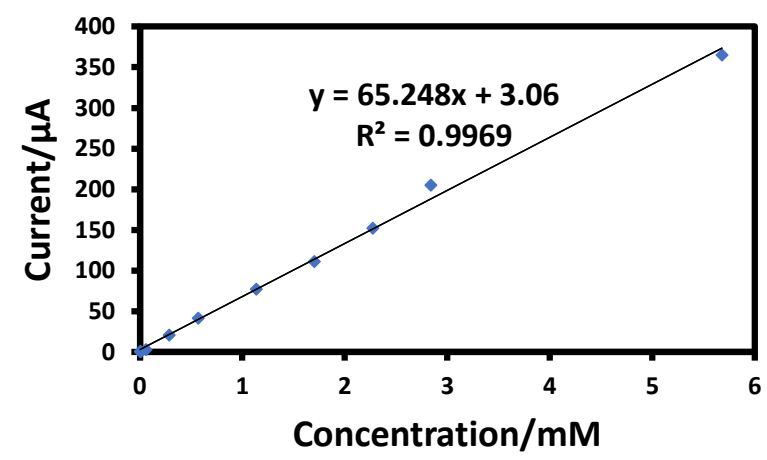

Fig.5. An extended calibration curve shows the relationship between ascorbic acid concentration in ppm and the oxidation peak current measured from cyclic voltammograms for ascorbic acid in $0.1 \mathrm{M} \mathrm{KCl}$ at iodine-coated platinum electrode. Scan rate $=50 \mathrm{mv}^{\star} \mathrm{s}^{-1}$.

\section{Potential interference}

The influence of vitamins B1, B6, B1, folic acid, citric acid, sucrose, glucose, and zinc were investigated in order to verify the existence of matrix effects of vitamin $C$ capsules and multivitamins tablets on ascorbic acid determination using cyclic voltammetry. The recorded cyclic voltammograms for each of these compounds show the absence of any electrochemical response of iodine-coated platinum electrodes toward these compounds. Figure 6 shows the recorded voltammograms for a solution of Multivitamin sample (control) and after each addition of a known concentration of the ascorbic acid standard solution. The result proved the absence of any possible interference with ascorbic acid despite the various components included in the Multivitamin sample, Vitamin $E$, B1, B2, B6, Folic acid, Pantothenic acid, Biotin, and Niacin. 


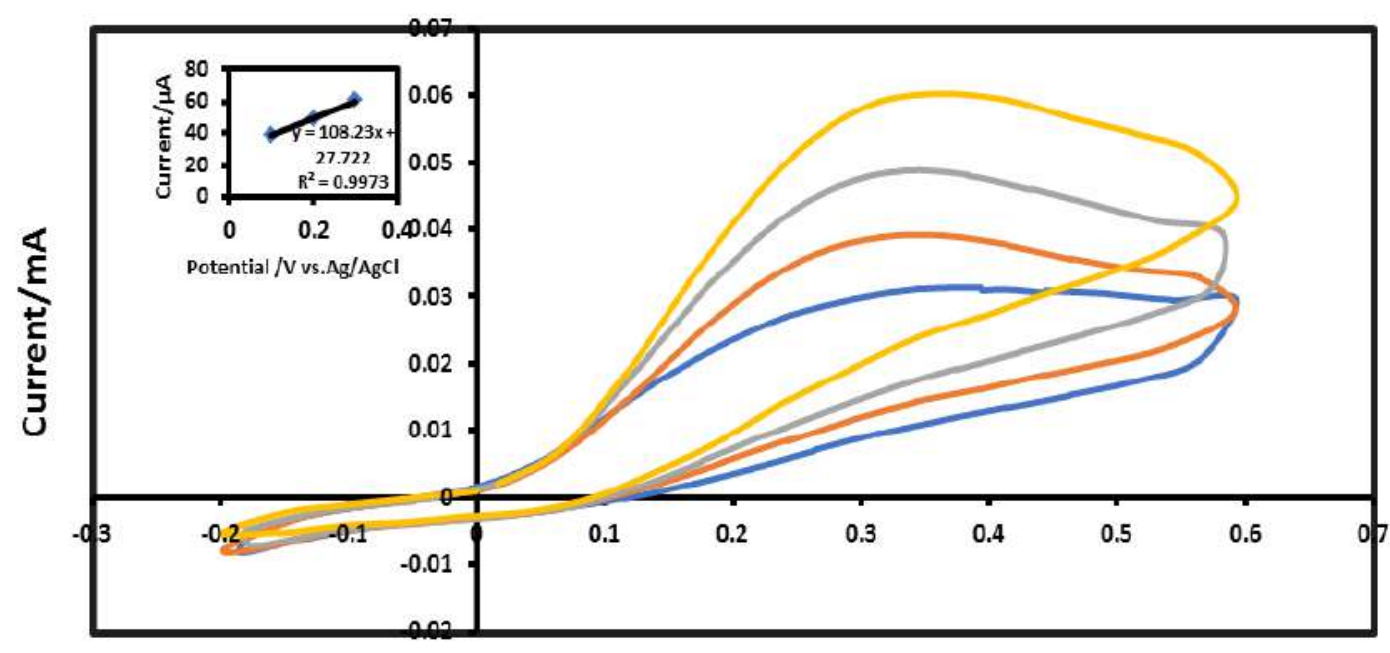

Potential/Vvs. Ag/AgCl

Fig.6: Cyclic voltammograms of iodine-coated platinum electrode in $0.1 \mathrm{M} \mathrm{KCl}$ containing Multivitamin tablet solution with addition of $0.1,0.2$, and $0.3 \mathrm{mM}$ of ascorbic acid standard solution. Scan rate $=50 \mathrm{mV} / \mathrm{s}$.

\section{RECOVERY}

The recovery experiment can be taken as evidence for the absence of interference. The feasibility of the developed voltammetric method for ascorbic acid determination was tested for three pharmaceutical formulation samples. Ascorbic acid standards of known concentration, 50 ppm and 60 ppm, were spiked into samples of tablet solutions in order to evaluate the percentage recovery for each brand of ascorbic acid. As listed in Table 1, the recovery values were found between $98.93 \pm 2.78$ and $99.98 \pm 5.20$ for all samples of ascorbic acid brands, showing the appropriateness of the iodine-coated platinum electrode for the quantitative analysis of ascorbic acid in pharmaceutical formulations.

Table 1. Recoveries of ascorbic acid from spiked pharmaceutical formulations obtained by the developed method

\begin{tabular}{|l|c|c|c|c|}
\hline \multicolumn{1}{|c|}{ Samples } & Content of ascorbic acid (mM) & Spiked ascorbic acid (mM) & Detected ascorbic acid after addition (mM), & \% Recovery \\
\hline Vitamin C plus $^{\circledR}$ & 0.28 & 0.227 & 0.51 & $99.98 \pm 5.20$ \\
\hline${\text { Multivit }{ }^{\circledR}}^{\circledR}$ & 0.28 & 0.227 & 0.51 & $98.93 \pm 2.78$ \\
\hline${\text { Vitamin C } 1000^{\circledR}}^{\circledR}$ & 0.568 & 0.341 & 0.787 & $99.80 \pm 2.50$ \\
\hline
\end{tabular}

\section{Pharmaceutical preparation analysis}

The developed voltammetric method was used to analyze ascorbic acid in three brands of the pharmaceutical formulation, multivitamin tablets, and two brands of vitamin C capsules (Vito + multivitamin, vitamin C plus, and vitamin C 1000). The method of standard addition was applied to diluted sample analysis to avoid the matrix effect. The estimation of the concentration of ascorbic acid was more convenient with the aid of a calibration graph. The results for the analysis of these pharmaceutical formulations with the developed voltammetric method are given in Table 2 .
The results obtained by using a cyclic voltammetry technique at iodine-coated platinum electrode were compared with the labeled values claimed by manufacturers. The data displayed in Table 2 show that all nominal values are within the confidence interval of $95 \%$, which confirms the manifest absence of errors in the results. The relative errors of the analysis of the three types of pharmaceutical formulations were lower than $5 \%$, certifying the accuracy of the developed voltammetric method. The measured coefficient of variation values $(0.55$ $2.19 \%$ ) was considered obvious evidence of the precision of the developed voltammetric method. 
The paired t-test was used to test the significant difference at $95 \%$ confidence level between the labeled values and the obtained results determined by the developed method. Comparing the calculated t value (0.0039) with the critical t value
(4.30 at $p=0.05)(33)$, it is shown that the obtained result supported the null hypothesis and indicated no significant difference between the values obtained by the applied voltammetric method and the nominal value obtained from manufacturers.

Table 2. Ascorbic acid (Vitamin C) content in pharmaceutical formulations collected from the Jordanian local pharmacies as determined by cyclic voltammetry at iodine-coated platinum electrode.

\begin{tabular}{|l|c|c|c|c|c|c|}
\hline $\begin{array}{c}\text { Pharmaceutical } \\
\text { preparation }\end{array}$ & $\begin{array}{c}\text { Nominal mass(in mg of ascorbic } \\
\text { acid/capsule or tablet) }\end{array}$ & $\begin{array}{c}\text { Average of determined } \\
\text { mass(in mg) of ascorbic } \\
\text { acid/capsule or tablet(n=3) }\end{array}$ & $\begin{array}{c}\text { Standard } \\
\text { deviation }\end{array}$ & $\begin{array}{c}\text { 95\% confidence } \\
\text { limits }\end{array}$ & $\begin{array}{c}\text { Relative } \\
\text { error }\end{array}$ & $\begin{array}{c}\text { Coefficient } \\
\text { of variation }\end{array}$ \\
\hline Vitamin C plus & & 497.42 & 3.18 & $497.42 \pm 7.90$ & 0.516 & $0.64 \%$ \\
\hline Multivitamin $^{\circledR}$ & 500 & 60.32 & 1.32 & $60.31 \pm 3.28$ & 0.53 & $2.19 \%$ \\
\hline Vitamin $\mathrm{C}^{\circledR}$ & $6000^{\circledR}$ & 907.53 & 5.48 & $997.531 \pm 13.61$ & 0.247 & $0.55 \%$ \\
\hline
\end{tabular}

A comparison between the developed voltammetric method and some of the common analytical and voltammetric methods for ascorbic acid determination in terms of detection limit and the linear range was displayed in Table 3. As shown, the iodine-coated platinum electrode exhibited a lower detection limit than that of other voltammetric methods (34-36). In contrast, the obtained linear range was convenient and extended compared to other voltammetric methods. Also, the developed method has the advantages of simplicity in sample preparations and analysis, side by side with a short time of analysis and the low price of instrumentations compared with other methods (Table 3).

Table 3. A comparison of analytical performance of developed voltammetric method using iodine-coated platinum electrode with other analytical methods reported in literature

\begin{tabular}{|l|c|c|c|}
\hline \multicolumn{1}{|c|}{ Method } & Linear range & Detection Limit(ppm) & Reference \\
\hline HPLC & $56.78 \mu \mathrm{M}-0.57 \mathrm{mM}$ & $1.7 \times 10^{-4} \mathrm{mM}$ & {$[5]$} \\
\hline Spectrophotometry & $\begin{array}{c}\text { Method A:3.69 } \mu \mathrm{M}-63.59 \mu \mathrm{M} \\
\text { Method B:2.9 } \mu \mathrm{M}-90.85 \mu \mathrm{M}\end{array}$ & Method A=0.85 $\mu \mathrm{M}$, Method B=1.1 $\mu \mathrm{M}$ & {$[4]$} \\
\hline Fluorometry & $0.7 \mu \mathrm{M}-6.02 \mu \mathrm{M}$ & $0.23 \mu \mathrm{M}$ & {$[13]$} \\
\hline Cyclic voltammetry & $0.01 \mathrm{mM}-0.101 \mathrm{mM}$ & $1.76 \mu \mathrm{M}$ & {$[34]$} \\
\hline Differential pulse voltammetry & $19.0 \mu \mathrm{M}-0.21 \mathrm{mM}$ & $19.0 \mu \mathrm{M}$ & {$[35]$} \\
\hline Square-wave voltammetry & - & $1.87 \mu \mathrm{M}$ & {$[36]$} \\
\hline Voltammetry & $2.84 \mu \mathrm{M}-5.68 \mathrm{mM}$ & $0.96 \mu \mathrm{M}$ & This work \\
\hline
\end{tabular}

\section{CONCLUSION}

In this work, a successive use of an iodine-coated platinum electrode to determine ascorbic acid was achieved. The developed method excludes any sophisticated procedures. In contrast, it is considered an applicable method for the simplicity of analysis procedures. The reported extended dynamic range $2.84 \times 10-3-5.68 \mathrm{mM}$ of ascorbic acid boosts the applicability of the voltammetric method for ascorbic acid determination in pharmaceutical products. Based on the recovery experiment, the absence of any interference from the other ingredients of pharmaceutical formulations is considered an evident indicator of the selectivity of the developed method. The analysis of the results statistically showed the absence of significant difference between the values obtained from the voltammetric method and the labeled values claimed by the manufacturers. 


\section{AKNOWLEDGMENT}

The authors (Mohammad Amayreh \& Wafa Hourani) is thankful to Dr.Mohammed Hourani from the Department of Chemistry, The University of Jordan, for his continuous support and encouragement and for providing the electrochemical workstation.

\section{CONFLICT OF INTEREST}

The authors declare that there is no conflict of interest

\section{AUTHORS' DECLARATION}

The authors hereby declare that the work presented in this article is original and that they will bear any liability for claims relating to the content of this article.

\section{REFERENCES}

1. Pisoschi AM, Danet AF, Kalinowski S. Ascorbic acid determination in commercial fruit juice samples by cyclic voltammetry. J Autom Methods Manag Chem. 2008; 2008:1-8 https://doi. org/10.1155/2008/937651

2. Chambial S, Dwivedi S, Shukla KK, John PJ, Sharma P. Vitamin $C$ in disease prevention and cure: An Overview. Indian Journal of Clinical Biochemistry.2013; 28(4), 314-328. https://doi. org/10.1007/s12291-013-0375-3

3. Perry M, Page N, Manthey D, Zavitz J. Scurvy: Dietary Discretion in a developed country. Clinical Practice and Cases in Emergency Medicine. 2018; 2(2): 147-150. https://doi.org/10.5811/ cpcem.2018.1.36860

4. Naidu KA. Vitamin $C$ in human health and disease is still a mystery? An overview. Nutrition Journal. 2003; 2:1-10. https:// doi.org/10.1186/1475-2891-2-7

5. Hu L, Li L, Luo Z, Yang J, Liu W. Determination of trace vitamin $C$ by ion-pair HPLC with UV detection in calcium gluconate and vitamin C compound oral solution. Journal of Chromatographic Science.2012; 50(2):102-107. https://doi.org/10.1093/chromsci/ bmr035

6. Gazdik Z, Zitka O, Petrlova J, Adam V, Zehnalek J, Horna A, Reznicek V, Beklova M, Kizek, R. Determination of vitamin C (Ascorbic Acid) using high performance liquid chromatography coupled with electrochemical detection. Sensors.2008; 8(11): 7097-7112. https://doi.org/10.3390/s8117097

7. Shrestha N, Shrestha S, Bhattarai A. Determination of ascorbic acid in different citrus fruits of Kathmandu Valley. Journal of medical and Biological Science Research. 2016; 2(1):9-14.

8. Anal PD, Shuchi, D. UV spectroscopic method for determination of vitamin C(ascorbic acid) content in different fruits in south Gujarat Region. International Journal of Environmental Sciences \& Natural Resources. 2019; 21(2):41-44. https://doi.org/10.19080/ IJESNR.2019.21.556056

9. Mirsad S, Amra S. Spectrophotometric determination of L-ascorbic Acid in pharmaceutical based on its oxidation by potassium peroxymonosulfate and hydrogen Peroxide. Croatica Chemica Acta. 2015; 88:73-79. https://doi.org/10.5562/cca2551
10. Zanini DJ, Silva MH, Aguiar-Oliveira E, Mazalli MR, Kamimura ES, Maldonado RR. Spectrophotometric analysis of vitamin $C$ in different matrices utilizing potassium permanganate. European International Journal of Science and Technology. 2018; 7(1):70-84.

11. Arya SP, Mahajan M, Jain P. Photometric methods for the determination of vitamin C. Analytical Sciences.1998; 14:889-895.

12. Lau O-W, Luk S-F, Wong K-S. Determination of ascorbic acid in pharmaceuticals using direct ultraviolet spectrophotometry. Analyst. 1987; 112:1023-1025.

13. Dilgin $Y$, Nisli G. Fluorimetric determination of ascorbic acid in vitamin C tablets using methylene blue. Chem. Pharm. Bull. 2015; 53:1251-1254. https://doi.org/10.1248/cpb.53.1251

14. Ensafi AA, Rezaei B. Flow injection analysis determination of ascorbic acid with spectrofluorimetric detection. Analytical Letters. 1998; 31:333-342. https://doi.org/10.1080/00032719808002049

15. Gazdik Z, Zitka O, Petrlova J, AdamV, Zehnalek J, Horna A, Reznicek V, Beklova M, kizek R. Determination of vitamin $\mathrm{C}$ (ascorbic acid) using high performance liquid chromatography coupled with electrochemical detection. Sensors.2008; 8(11):7097-7112. https://doi.org/10.3390/s8117097

16. Clucu AA. Chemically modified electrodes in biosensing. $J$ Biosens Bioelectron.2014; 5(3):1-10. https://doi.org/10.4172/21556210.1000154

17. March G, Nguyen TD, Piro B. Modified electrodes used for electrochemical detection of metal ions in environmental analysis. Biosensor. 2015; 5(2):241-275. https://doi.org/10.3390/ bios5020241

18. Cox JA, Kulesza PJ. Oxidation and determination of nitrite at modified electrodes. Journal of Electroanalytical Chemistry and Interfacialelectrochemistry.1984; 175(1-2): 105-118. https:// doi.org/10.1016/S0022-0728(84)80349-6

19. Felter TE, Hubbard AT. L.E.E.D. and electrochemistry of iodine on Pt (100) and Pt (111) single-crystal surfaces. J. Electroanal. Chem.1979, 100:473-491. https://doi.org/10.1016/S00220728(79)80179-5

20. Shu ZX, Bruckenstein S. Iodine Adsorption Studies at Platinum. J. Electroanal. Chem.1991, 317:263-277. https://doi. org/10.1016/0022-0728(91)85019-L

21. Mebrahtu T, Rodriguez JF, Bravo BG, Soriaga MP. Hydrogenative/ cathodic stripping of iodine chemisorbed on smooth polycrystalline platinum electrode. J. Electroanal. Chem. 1987, 219, 327-333. https://doi.org/10.1016/0022-0728(87)85050-7

22. Thomas AE, Wieckowski A. Surface diffusion limited desorption of iodine on a platinum electrode?. Journal of Electroanalytical Chemistry.1995; 399:207-212. https://doi.org/10.1016/00220728(95)04226-1

23. Podlovchenko BI, Kolyadko EA. Adsorption of carbon monoxide on platinized platinum electrode with preadsorbed iodine and iodide Anions. Russian Journal of Electrochemistry. 2003; 39: 823-827.

24. Hourani MK. Determination of silver (I) by cyclic voltammetry at iodine-coated electrodes. Analyst. 1994; 119: 1975-1978. https:// doi.org/10.1039/AN9941901975

25. Lane RF, Hubbard AT, Fukunaga K, Blanchard RJ. Brain catecholamines: detection in vivo by means of differential pulse voltammetry at surface-modified platinum electrodes. Brain Research. 1976; 114(2): 346-352. https://doi.org/10.1016/00068993(76)90678-8

26. Hourani M, Jarar A, Arar S. Atmospheric $\mathrm{SO}_{2}$ determination by voltammetric analysis at an iodine-coated platinum electrode. Electroanalysis.1999; 11(9):637-640. https://doi.org/10.1002/ (SICI)1521-4109(199907)11:9<637::AID-ELAN637>3.0.CO;2-R 
27. Hourani Mk, Hijaz B. Voltammetric Analysis of Hydroquinone and Catechol at lodine-Coated Polycrystalline Platinum Electrode. Journal of Natural and engineering Science.2014; 8(2): 25-29.

28. Amayreh M, Hourani MK. Determination of iron in dietary supplements by voltammetric analysis at an iodine-coated polycrystalline platinum electrode. Int.J. Electrochem. Sci. 2018; 13: 975-983. https://doi.org/10.20964/2018.01.81

29. Amayreh $M$, Hournai MK. Direct determination of hemoglobin in blood using iodine-coated platinum polycrystalline electrode. Analytical and Bioanalytical Chemistry Research. 2019; 6(1): 5968. https://doi.org/10.22036/ABCR.2018.125953.1198.

30. Hournai MK, Amayreh M, Hourani W. A Voltammetric sensor based on iodine-coated platinum electrode for determination of iron in blood serum. Anal.Bioanal.Electrochem. 2018; 10(12):16201628.

31. Amayreh M, Hourani M. Determination of Iron in Spinach Using Sweep Voltammetry at lodine-Coated Platinum rotating Disk Electrode. Journal of AOAC International. 2019; 102(2):666-668. https://doi.org/10.5740/jaoacint.18-0267.
32. Amayreh M, Hourani W, Hourani MK. Anodic Stripping Voltammetric Determination of Copper in Multivitamin-Mineral Formulations using lodine-Coated Platinum Electrode. Methods Objects Chem. Anal.2021,16(1),48-56. https://doi.org/10.17721/ moca.2021.48-56

33. Miller JN, Miller JC Statistics and Chemometrics for Analytical Chemistry. $6^{\text {th }}$ ed. Pearson, England;2010.43-45p.

34. Bitew Z, Amare M. Electrochemical determination of ascorbic acid in pharmaceutical tablets using carbon paste electrode. Organic \& Medicinal Chemistry International Journal. 2019; 8(5):19. https://doi.org/10.19080/OMCIJ.2019.08.555749

35. Lourenção BC, Medeiros RA, Rocha-Filho RC, Fatibello-Filho $\mathrm{O}$, Simultaneous differential pulse voltammetric determination of ascorbic acid and caffeine in pharmaceutical formulations using a boron-doped diamond electrode. Electroanalysis.2010; 22(15):1717-1723. https://doi.org/10.1002/elan.200900612

36. Vedenyapina MD, Kazakova MM, Skundin AM. Voltammetric determination of ascorbic acid in pharmaceutical formulation on a boron doped diamond electrode. Russ. J. Phys. Chem. 2019; 93: 1178-1181. https://doi.org/10.1134/S0036024419060335 